\title{
DETERMINAN PROFITABILITAS BANK MELALUI Z-SCORE, STRUKTUR MODAL, SIZE, RISIKO KREDIT DAN PERMODALAN PADA INDUSTRI PERBANKAN NASIONAL
}

\author{
Anton Ferry Ananda \\ Sekolah Tinggi Ilmu Ekonomi Kertanegara Malang \\ Jl. Cengger Ayam I No. 5 Malang
}

\begin{abstract}
This study aimed to analyze the influence of the value of the Z-Score, capital structure, size, credit risk and capital as measured by CAR on bank profitability. The object of this study is on the national banking industry. The sampling technique used in this research is purposive sampling. The sample in this study is a bank which went public on the Stock Exchange prior to the year 2013 and to publish financial statements in 2013 and 2014. The samples were 27 banks. Period study in 2013 and 2014. The analysis technique used multiple linear regression. The results showed that simultaneous Z-Score, capital structure, size, credit risk and capital effect on profitability. Partially value of the Z-Score, size, risk and CAR effect on profitability, while the capital structure policy has no effect on profitability.
\end{abstract}

Keyword: profitability, Z-Score, debt to Equity ratio, non performance loan, CAR.

DOI : http://dx.doi.org/10.21067/jem.v12i1.1179

Diterima : Desember 2015; Direvisi: Januari 2016; Diterima : February 2016

\section{PENDAHULUAN}

Industri perbankan sebagai lembaga intermediasi memegang peran yang penting dalam perekonomian, dimana 80 persen pembiayaan oleh lembaga keuangan dilakukan oleh perbankan melalui kredit (Astohar, 2009). Bank dapat melakukan fungsi intermediasi dengan baik, jika bank tersebut sehat. Bank yang sehat akan membuat kepercayaan masyarakat tetap terjaga, mengingat kepercayaan masyarakat merupakan modal yang penting bagi bank.

* Corresponding Author.

E-mail: antonfery@gmail.com
Bank yang sehat menunjukkan bank itu efisien, sehingga price yang ditawarkan bank akan rendah. Price berupa bunga kredit yang rendah akan membuat investasi dan usaha bergairah dan berkembang. Bank sebagai industri yang dalam kegiatan utamanya sebagai lembaga intermediasi, maka kepercayaan masyarakat merupakan modal yang sangat penting. Untuk itu bank dituntut dapat menjaga tingkat kesehatan dan kinerja banknya (Merkusiwati, 2007). Bank yang sehat akan membuat kepercayaan masyarakat akan semakin tinggi.

Bank sebagai suatu perusahaan bertujuan untuk memperoleh laba. Bank dengan laba yang semakin tinggi menunjukkan bank tersebut semakin sehat. Bank Indonesia telah 
mengeluarkan peraturan mengenai penilaian kesehatan bank melalui Peraturan Bank Indonesia No. 6/10/PBI/2004 tanggal 12 April 2004 berisi tentang panduan dalam menilai tingkat kesehatan bank dengan menggunakan CAMELS. Peraturan ini kemudian diperbaharui dengan Peraturan Bank Indonesia No. 13/1/PBI/2011 sebagaimana diatur dalam surat edaran No. 13/24/DPNP tanggal 25 Oktober 2011. Bank Indonesia menetapkan penilaian tingkat kesehatan bank yang didasarkan pada pendekatan risiko (risk based bank rating). Dimana penilaian kesehatan bank meliputi 4 hal, yaitu risk profile, Penerapan Good Corporate Governance (GCG), Earning dan Capital. Earning menunjukkan tingkat kemampulabaan atau profitabilitas bank dalam menggunakan aset atau aktiva yang dimilikinya. Dimana semakin tinggi Earning suatu bank menunjukkan bank tersebut semakin sehat.

Salah satu ukuran profitabilitas suatu bank adalah Return on Asset (ROA). ROA penting bagi bank karena ROA digunakan untuk mengukur efektivitas perusahaan di dalam menghasilkan keuntungan dengan memanfaatkan aktiva yang dimilikinya. ROA merupakan rasio antara laba sesudah pajak terhadap total asset. Semakin besar ROA menunjukkan kinerja perusahaan semakin baik, karena tingkat kembalian (return) semakin besar (Husnan dan Pudjiastutik, 2004).

Profitabilitas mempunyai makna yang penting, baik bagi perusahaan maupun stakeholdernya. Perusahaan dengan profitabilitas yang baik menunjukkan perusahaan mempunyai prospek yang baik, perusahaan akan mampu mempertahankan kelangsungan perusahaan dalam jangka panjang (Haryanto, 2016).

ROA merupakan indikator profitabilitas yang sering digunakan untuk menilai profitabilitas bank. Bank Indonesia selaku pembina dan pengawas perbankan lebih mengutamakan nilai profitabilitas suatu bank yang diukur ROA. Hal ini karena ROA mengukur profitabilitas bank yang didasarkan dari nilai asset, dimana sebagian besar aset bank berasal dari dana masyarakat atau dana pihak ketiga (DPK) (Haryanto, 2015). ROA digunakan untuk mengukur efisiensi dan efektifitas perusahaan didalam menghasilkan keuntungan dengan memanfaatkan aktiva yang dimilikinya.

Profitabilitas merupakan hasil dari kebijakan dan keputusan yang diambil perusahaan. Profitabilitas bank antara lain dipengaruhi oleh, CAR, LDR,BOPO, dan NPL (Mabruroh, 2004; Limphapayom dan Polwitoon, 2004; dan Suyono, 2005).

Altman Z-score merupakan indikator untuk mengukur potensi kebangkrutan suatu perusahaan. Nilai Z-score merupakan hasil penjumlahan dari perkalian lima unsur rasio dengan koefisiennya. Rasio-rasio tersebut menunjukkan kemampuan manajemen di dalam mengelola aktiva perusahaan. Altman Z-score dapat digunakan untuk mengukur kinerja perusahaan, yaitu dari sisi potensi kebangkrutan suatu perusahaan. Semakin tinggi nilai $Z$-score menunjukkan kinerja perusahaan akan semakin baik, karena memilki prospek yang semakin bagus di masa depan. Sehingga semakin tinggi nilai Z-score profitabilitas akan semakin tinggi.

Salah satu keputusan perusahaan adalah kebijakan struktur modal. Perubahaan harus memutuskan sumber-sumber pembiayaan untuk kegiatannya. Keputusan sumber dana akan terkait dengan masalah risk dan return perusahaan. Perusahaan dengan sumber pembiayaan yang besar dari luar akan cenderung memiliki risiko keuangan yang tinggi, karena harus membayar bunga pinjaman pada pihak luar. Sebaliknya, perusahaan jika menggunakan modal sendiri kemungkinan perusahaan akan kurang efektif. Keputusan struktur modal yang efektif dapat merendahkan biaya modal yang dikeluarkan oleh perusahaan, sebaliknya jika struktur modal yang buruk akan berpengaruh pada besarnya biaya modal perusahaan yang akan dikeluarkan (Nugraha, 2013). Hasil penelitian menunjukkan hasil yang tidak konsisten. Bukit (2012), Wahyuni (2012) menunjukkan bahwa struktur modal berpengaruh terhadap profitabilitas. Karina dan Khafid (2015) struktur modal tidak berpengaruh terhadap profitabilitas, sedangkan penelitian Nugraha (2013) struktur modal tidak berpengaruh terhadap kinerja perusahaan. 
Perusahaan dengan aset yang besar, baik itu dibiayai dengan hutang maupun modal sendiri cenderung akan mempunyai kemampuan lebih untuk mengakses ke pasar modal untuk mendapatkan tambahan dana sehingga mampu meningkatkan profitabilitas (Kristantri \& Rasmini, 2012). Hasil penelitian Suteja dan Ginting (2014) menunjukkan Size berpengaruh terhadap profitabilitas. Sedangkan Karina dan Khafid (2015) menunjukkan Size tidak berpengaruh terhadap profitabilitas.

Bank sebagai lembaga intermediasi, ketika menyalurkan kredit akan dihadapkan pada risiko. Non Performance Loans (NPL) merupakan merupakan indikator dari risiko kredit bank. Bank dengan NPL yang tinggi cenderung kurang efisien. Sebaliknya bank dengan NPL yang rendah, maka bank tersebut cenderung lebih efisien. Bank dengan NPL yang semakin rendah akan memiliki kemampuan menyalurkan dananya kepada nasabah lainnya sehingga tingkat profitabilitasnya akan semakin tinggi (Priantana dan Zulfia, 2011). Hasil penelitian menunjukkan hasil yang tidak konsisten. Temuan penelitian Molyneux \& Thornton (1992) menunjukkan hubungan negatif dan signifikan antara tingkat likuiditas dan profitabilitas. Berbeda dengan temuan penelitian Bourke (1989) menemukan hasil yang sebaliknya, sementara temuan Subandi dan Ghozali (2013) menunjukkan bahwa NPL tidak berpengaruh terhadap profitabilitas.

Permodalan dalam bank merupakan faktor penting dalam penilaian kesehatan bank baik dengan didasarkan pada CAMELS maupun pada pendekatan risiko (risk based bank rating) dengan Peraturan Bank Indonesia No. 13/1/PBI/2011 sebagaimana diatur dalam surat edaran No. 13/24/DPNP tanggal 25 Oktober 2011. Peranan modal sangat penting dalam usaha perbankan karena dapat mendukung kegiatan oprasional bank agar dapat berjalan dengan lancar (Sari, 2013). Bank dengan CAR cukup besar akan mampu mendukung pengembangan operasi dan kelangsungan hidup bank serta menanggung risiko-risiko yang ditimbulkan termasuk di dalamnya risiko kredit sehingga akan mampu meningkatkan profitabilitas bank. Hasil penelitian pengaruh CAR terhadap profitabilitas menunjukkan hasil yang belum konsisten. Temuan penelitian Limpaphayom dan Polwitoon (2004) menunjukkan adanya pengaruh yang negatif antara CAR terhadap ROA. Sebaliknya, temuan penelitian Gelos (2006) dan Suyono (2005) yang menunjukkan adanya pengaruh yang signifikan positif antara CAR dengan ROA.

Berdasarkan riset gap tersebut, maka tujuan penelitian ini adalah untuk menganalisis pengaruh nilai Z-Score, struktur modal, size, risiko kredit, dan permodalan bank terhadap profitabilitas.

\section{TINJAUAN PUSTAKA Profitabilitas Bank}

Salah satu tujuan bank sebagai suatu perusahaan adalah memperoleh profitabilitas yang tinggi. Semakin tinggi profitabilitas suatu bank maka akan semakin sehat bank tersebut. Bank Indonesia selaku lembaga yang mempunyai tugas untuk mengawai industri perbankan di Indonesia telah menetapkan tentang penilaian kesehatan bank. PBI No. 6/10/PBI/2004 tanggal 12 April 2004 telah mengatur tentang menilai tingkat kesehatan bank dengan menggunakan CAMELS. Akibat krisis keuangan global tahun 2008, Bank Indonesia telah mengeluarkan PBI No. 13/1/PBI/2011 sebagaimana diatur dalam surat edaran No. 13/24/DPNP tanggal 25 Oktober 2011 yang mengatur tentang penilaian tingkat kesehatan Bank didasarkan pada pendekatan risiko (risk based bank rating).

Profitabilitas menunjukkan kemampuan bank dalam memperoleh laba dengan mengelola aset yang dimiliki. Semakin tinggi profitabilitas suatu bank menunjukkan bank tersebut semakin baik dalam mengelola aset. Profitabilitas mempunyai makna yang penting bagi perusahaan dan stake holdernya Profitabilitas yang tinggi menunjukkan prospek perusahaan baik, sehingga investor akan merespon positif sinyal tersebut dan nilai perusahaan akan meningkat (Sujoko dan Ugi, 2007).

Profitabilitas merupakan indikator yang paling tepat untuk mengukur kinerja bank (Sofyan: 2003). Dimana Bank Indonesia sebagai pembina dan pengawas perbankan lebih mengutamakan nilai profitabilitas suatu bank yang diukur dari nilai aset yang dananya 
sebagian besar berasal dari dana masyakat atau dana pihak ketiga (DPK). Hal ini karena ROA mengukur efisiensi dan efektifitas perusahaan didalam menghasilkan keuntungan dengan memanfaatkan aktiva yang dimilikinya. Dimana salah sumber pembiayaan aktiva terbesar berasal dari DPK.

\section{Kesulitan Keuangan dan Kebangkrutan}

Kesulitan keuangan (financial distress) adalah kondisi dimana perusahaan berada dalam kesulitan keuangan sehingga tidak dapat menyediakan dana untuk memenuhi hutang lancarnya. Plat dan Plat (2006) mendefinisikan financial distress sebagai tahap penurunan kondisi keuangan yang terjadi sebelum terjadinya kebangkrutan ataupun likuidasi. Financial distress adalah ditandai dengan situasi dimana arus kas operasi perusahaan tidak memadahi untuk melunasi kewajiban-kewajiban lancar sehingga perusahaan terpaksa melakukan tindakan perbaikan. Perusahaan akan melakukan perubahan ukuran operasi atau struktur perusahaan (Hapsari, 2012).

Kebangkrutan (bangruptcy) suatu perusahaan ditandai dengan financial distress, yaitu keadaan dimana perusahaan lemah dalam menghasilkan laba atau perusahaan cenderung mengalami defisit. Kebangkrutan merupakan kondisi di mana perusahaan tidak mampu lagi untuk melunasi kewajibannya (Prihadi, 2008). Kebangkrutan sebagai kegagalan diartikan sebagai kegagalan keuangan atau financial failure dan kegagalan ekonomi atau economic failure (Adnan dan Kurniasih, 2000). Kebangkrutan perusahaan menunjukkan kegagalan suatu perusahaan (Andrian dan Khoiruddin 2014). Salah satu analisis untuk menilai kebangkrutan suatu perusahaan dikembangkan oleh Altman (1968). Altman mengembangkan metode kebangkrutan dengan tingkat keakuratan yang dapat dipercaya dalam memprediksi kebangkrutan.

\section{Kebijakan Struktur Modal}

Keputusan manajerial yang penting yang harus diambil manajemen adalah bagaimana manajemen menentukan sumber pendanaan bagi perusahaan, yang tercermin dari struktur modal perusahaan (Haryanto, 2014). Bank sebagai suatu perusahaan yang berorientasi laba akan memutuskan sumber pembiayaan untuk membiayai dan pengembangan pengembangan bisnisnya. Sumber dana tersebut dapat berasal dari sumber internal ataupun sumber eksternal. Keputusan terkait dengan sumber dana dikenal dengan kebijakan struktur modal. Kebijakan struktur modal merupakan suatu kebijakan yang menyangkut kombinasi yang optimal dari penggunaan berbagai sumber dana yang akan digunakan untuk membiayai suatu investasi dan juga untuk mendukung operasional perusahaan dalam usaha untuk meningkatkan laba (profit) perusahaan dalam rangka mencapai nilai perusahaan yang tinggi (Gitman, 2009). Manajemen dalam melakukan keputusan pendanaan, akan mempertimbangkan dan menganalisis kombinasi sumber-sumber dana ekonomis guna membelanjai kebutuhankebutuhan investasi serta kegiatan usahanya. Pertimbangan cost of capital (COC) sangat penting dalam menentukan struktur modal, karena kebijakan mengenai struktur modal melibatkan trade off antara risiko dan tingkat pengembalian (Brigham dan Erhardt, 2005).

Manajemen akan berusaha bagaimana mengambil kebijakan struktur modal yang optimal. Struktur modal yang optimal adalah struktur modal yang mengoptimalkan keseimbangan antara risiko dan pengembalian, sehingga akan mampu meningkatkan profitabilitas perusahaan. Struktur permodalan yang optimal merupakan target yang senantiasa dicapai oleh suatu perusahaan termasuk bank.

Bank merupakan lembaga keuangan dengan karakteristik usaha dengan banyak bertumpu pada dana masyarkat (DPK). Hal ini membuat struktur modal bank secara fundamental berbeda dengan perusahaan nonfinancial, karena karakteristik bisnis atau kegiatan operasionalnya berbeda (Siringoringo, 2012). Sesuai dengan regulasi dan dalam upaya melindungi dana deposan bank harus memiliki buffer sesuai dengan ketentuan penyediaan modal inti minimum (Saunders, 2008). 


\section{Ukuran Perusahaan (Size)}

Size menggambarkan besar kecilnya suatu perusahaan yang dapat dinilai dari total assets yang dimiliki, jumlah penjualan, rata-rata total penjualan dan rata-rata assets. Perusahi 4 yang semakin besar menunjukkan bahwa perusahaan tersebut telah mencapai tahap kedewasaan dan dianggap memiliki prospek yang baik dalam jangka waktu yang relatif lama, selain itu juga mencerminkan bahwa perusahaan relatif lebih stabil dan lebih mampu menghasilkan laba dibanding perusahaan dengan total asset yang kecil (Pangemanan \& Mawikere, 2011). Perusahaan besar lebih menjanjikan kinerja yang baik (Lin, 2006).

Perusahaan yang semakin besar akan cenderung lebih mudah memperoleh dana dari pasar modal dan menentukan kekuatan tawarmenawar (bargaining power) dalam kontrak keuangan. Moh'd et al (1998) mengemukakan bahwa perusahaan yang berukuran besar akan lebih mudah mengakses pendanaan melalui pasar modal. Perusahaan besar biasanya dapat memilih pendanaan dari berbagai bentuk utang, termasuk penawaran spesial yang lebih menguntungkan dibandingkan dengan perusahaan kecil. Kemudahan ini merupakan informasi baik bagi pengambilan keputusan investasi dan juga dapat merefleksikan nilai perusahaan di masa mendatang.

\section{Risiko Bank (Non Performance Loans)}

Bank ketika menyalurkan kredit, maka saat itulah risiko kredit akan menyertainya. Risiko kredit yang diterima bank merupakan salah satu risiko usaha bank, yang diakibatkan dari kegagalan nasabah mengembalikan jumlah pinjaman yang diterima dari bank beserta bunganya sesuai dengan jangka waktu yang ditentukan. Risiko ini dapat timbul karena kinerja satu atau lebih debitur yang buruk (Haryanto, 2015). Kredit macet bukan hanya disebabkan oleh kelemahan manajemen kredit oleh bank, namun juga dapat disebabkan oleh kegagalan usaha debitur karena manajemen usahanya maupun perubahan ekonomi yang memburuk.

Non Performance Loans (NPL) atau kredit bermasalah merupakan indikator yang seringkali digunakan untuk mengukur risiko kredit. Semakin tinggi NPL menunjukkan risiko kredit bank besar, sehingga bank cenderung tidak efisien. Apabila kredit bermasalah meningkat, maka risiko terjadinya penurunan profitabilitas semakin besar. Ketika profitabilitas bank menurun, akan berakibat pada kemampuan bank dalam melakukan ekspansi kredit berkurang.

\section{Capital Adequacy Ratio (CAR)}

Permodalan bank merupakan permasalahan yang penting dalam mendukung kegiatan operasionalnya serta untuk mampu bersaing secara global (Fitrianto dan Mawardi, 2006; 2009; Sari 2013, Haryanto, 2015). Bakbank di Indonesia dalam pemenuhan kebutuhan permodalan harus mengikuti Standard Bank for International Settlements (BIS). Bank harus memenuhi ketentuan Kewajiban Penyediaan Modal Minimum (KPMM) atau sering disebut CAR. Tingkat kebutuhan CAR bank adalah masalah mendasar tidak hanya di Indonesia, tetapi juga di semua negara.

CAR merupakan rasio permodalan yang menunjukkan kemampuan bank dalam menyediakan dana untuk keperluan pengembangan usaha (Ali, 2004). Bank dengan CAR yang semakin tinggi, maka semakin besar kemampuan bank dalam meminimalisir risiko kredit yang terjadi sehingga kredit bermasalah yang terjadi dalam bank akan semakin rendah dengan besarnya cadangan dana yang diperoleh dari perbandingan modal dan aktiva tertimbang menurut risiko (Ali, 2004).

\section{METODE}

Penelitian ini merupakan penelitian deskriptif kuantitatif dengan menggunakan data tahunan dari laporan keuangan Bank. Populasi dalam penelitian ini adalah bank yang go publik di BEI. Teknik sampling yang digunakan purposive sampling, yaitu dengan kriteria: 1) bank tersebut telah go publik sebelum tahun 2013, 2) bank tersebut mempublikasikan laporan keuangan tahun 2013-2014. Jumlah bank yang menjadi sampel dalam penelitian sejumlah 27 bank. Sumber data yang digunakan berupa data sekunder yang bersumber dari http:idx.co.id. Jenis data berupa berupa data kuantitif, yang berupa data laporan 
keuangan. Independent variable dalam penelitian ini meliputi: Nilai Z-Score, struktur modal, Size, risiko kredit dan permodalan bank (CAR). Dependent variable adalah profitabilitas yang diukur dengan ROA. Teknik pengambilan data dilakukan dengan dokumentasi, sedangkan teknik analisis data untuk mengetahui pengaruh independent variable terhadap dependent variable baik secara simultan maupun parsial digunakan regresi linear berganda. Model persamaan regresi berganda dirumuskan sebagai berikut:

$Y=\propto+\beta_{1} X_{1}+\beta_{2} X_{2}+\beta_{3} X_{3}+\beta_{4} X_{4}+\beta_{5} X_{5}$ Di mana:

Y : Profitabilitas (ROA)

$\alpha \quad$ : Konstanta

$\beta_{1-5}:$ Koefisien regresi

$\mathrm{X} 1$ : Nilai Z-Score

$\mathrm{X} 2$ : Struktur modal (Debt to Equity Ratio)

$\mathrm{X} 3$ : Size atau ukuran Perusahaan

X4 : Risiko Bank yang diukur dari NPF

X5 : Permodalabn bank (CAR)

e : Error

\section{HASIL}

Rerata profitabilitas (ROA) perbankan nasional tahun 2013-2014 sebesar 1,384 dengan ROA tertinggi sebesar 3,410 yang dicapai oleh Bank BRI tahun 2013. ROA terendah sebesar 1,320 yang dibukukan oleh Bank Pundi Indonesia (BEKS). Nilai Z-Score suatu bank yang semakin kecil menunjukan bank akan cenderung kurang baik, dan sebaliknya. Rerarta nilai Z-Score perbankan nasional perbankan nasional sebesar 4,026. Hal ini menunjukkan kondisi perbankan nasional cukup baik. Rerata CAR bank sebesar 23,8, dimana CAR diatas ketetentuan permodalan minimal yang harus dimilaki oleh bank. Risiko kredit yang ditunjukkan dari besarnya kredit bermasalah atau NPL masih di bawah ketentuan maksimum Bank Indonesia, dimana rerata NPL sebesar 2,149. Nilai NPL tertinggi terjadi pada Bank Pundi Indonesia (BEKS), yaitu sebesar 6,940 pada tahun 2014.

Size bank menunjukkan besarnya asset suatu bank. Rerata asset bank nasional masih belum begitu tinggi, jika dibandingkan dengan asset bank-bank di Negara-negara ASEAN. Rerata asset bank di Indonesia sebesar 148,55 Trilyun rupiah, dimana asset tertinggi dimiliki oleh Bank Mandiri sebesar 855,039 Trilyun pada tahun 2014. Struktur modal yang ditunjukkan oleh DER rerata perbankan nasional sebsar 7,961.

Tabel 1

Deskripsi Data Industri Perbankan Nasional

\begin{tabular}{|l|l|r|l|l|r|r|}
\hline & Z & \multicolumn{1}{|c|}{ DER } & Size & NPL & \multicolumn{1}{|c|}{ CAR } & ROA \\
\hline Rerata & 2,578 & 7,961 & 7,727 & 2,149 & 16,379 & 1,384 \\
\hline Maksimum & 4,026 & 13,220 & 8,932 & 6,940 & 23,800 & 3,410 \\
\hline Minimum & 2,005 & 4,780 & 6,556 & 0,210 & 9,700 & 1,320 \\
\hline
\end{tabular}

Sumber: data diolah 2016

Uji normalitas data dilakukan dengan melihat diagram normal pplot. Jika data menyebar mengikuti arah garis diagonal, maka data normal. Model regresi yang baik jika distribusi datanya normal atau mendekati normal. Hasil pengujian normalitas menunjukkan data berdistribusi normal (Gambar 1).

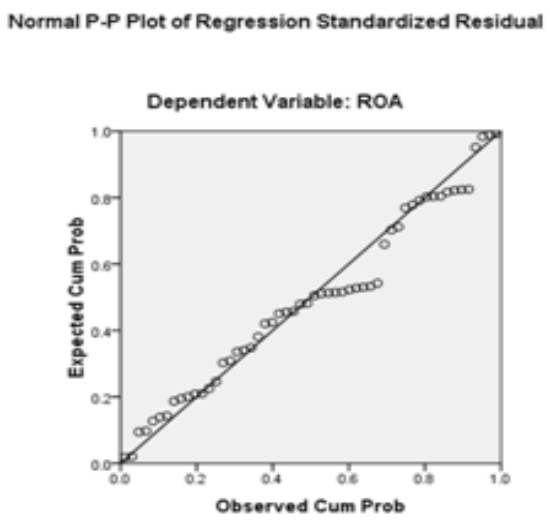

Gambar 1. Uji Normalitas Data

Uji heteroskedasitas dilakukan dengan menggunakan scatter plot antar nilai prediksi yang distandarisari (ZPRED) dengan nilai residual yang distandarisasi (SRESID). Pengujian heteroskedasitas dilakukan untuk mengetahui apakah terdapat hubungan antara variabel bebas dengan nilai residual. Hasil 
pengujian heteroskedasitas menunjukkan bahwa tidak terjadi heteroskedasitas, hal ini ditunjukkan scatterplot (Gambar 2). Dimana sebaran atau plot di scatter plot menunjukkan menyebar dan tidak membentuk suatu pola tertentu atau menyebar di atas dan di bawah angka nol pada sumbu studentized residual atau sumbu Y dan di kanan dan kiri sumbu standardized predicted value.

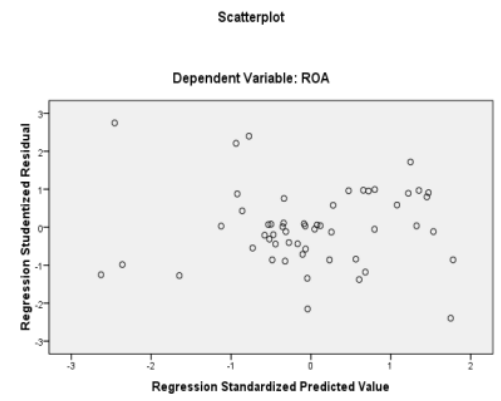

Gambar 2. Uji heteroskedasitas

Hasil pengujian autokorelasi menunjukkan nilai DW sebesar 1.836 (Tabel 2). Dengan jumlah data (n) sebanyak 54 dan jumlah variabel bebas 5 diperoleh nilai $\mathrm{DW}$ tabel $\mathrm{dU}$ 1,7684 dan dL sebesar 1,3669. Nilai DW hitung berada diantara dU $(1,7684)$ dan 4-dU $(2,2316)$ sehingga dapat disimpulan tidak terjadi autokorelasi. Pengujian multikolineritas dilakukan dengan menggunakan nilai Varian Inflation Factor (VIF). Model dikatakan tidak terjadi multikolineritas jika nilai VIFnya (Tabel 2) lebih kecil dari 10. Hasil pengujian nilai VIF di bawah 10, sehingga dapat disimpulkan tidak terjadi multikolineritas.

Tabel. 2 Ringkasan Hasil Analisis Data

\begin{tabular}{|c|c|c|c|c|c|}
\hline & $\begin{array}{c}\text { Standard } \\
\text { ized } \\
\text { Coef } \\
\text { Beta }\end{array}$ & $\mathrm{t}$ & Sig. & $\begin{array}{l}\text { Collinea } \\
\text { rity } \\
\text { Toleranc } \\
\text { e }\end{array}$ & VIF \\
\hline (Constant) & & $-3,650$ & 0,001 & & \\
\hline Z-Score & 0,287 & 2,471 & 0,017 & 0,604 & 1,656 \\
\hline $\begin{array}{l}\text { Struktur } \\
\text { Modal }\end{array}$ & $-0,033$ &,- 241 & 0,811 & 0,440 & 2,271 \\
\hline
\end{tabular}

\begin{tabular}{lrrrrr}
\hline $\begin{array}{l}\text { Size } \\
\text { Risiko }\end{array}$ & 0379 & 3,887 & 0,000 & 0,857 & 1,167 \\
$\begin{array}{l}\text { Kredit } \\
\text { Permodal } \\
\text { an }\end{array}$ & $-0,233$ & $-2,357$ & 0,023 & 0,837 & 1,195 \\
\hline $\mathrm{R}_{\text {Adj }}^{2}$ & $: 0,568$ & 2,536 & 0,015 & 0,653 & 1,533 \\
F $_{\text {hitung }}$ & $: 14,943$ & & & & \\
F & & & & & \\
Drob & $: 0,000$ & & & & \\
Dw & $: 1,736$ & & & &
\end{tabular}

Sumber: Hasil olahan data

Berdasarkan hasil pengujian secara simultan pengaruh variabel bebas (Nilai ZScore, Struktur Modal, Size, Risiko Kredit, dan Permodalan) terhadap profitabilitas menunjukkan nilai $\mathrm{F}$ hitung sebesar 14,943 dengan probabilitas sebesar 0,000. Nilai probabilitasnya lebih kecil dari 0,05 , sehingga dapat diambil keputusan bahwa secara simultan variabel bebas berpengaruh terhadap profitailitas pada industri perbankan nasional (Tabel 2). Nilai koefisien determinasi diseseuaikan ( $\mathrm{R}^{2}$ adj) sebesar 0,568. Hal ini menunjukkan bahwa variabel bebas yang ditunjukkan oleh Nilai Z-Score, Struktur Modal, Size, Risiko Kredit, dan Permodalan mampu menjelaskan varian profitabilitas sebesar 56,8 persen, sedang sisanya 43,2 persen dijelaskan oleh variabel lain diluar model.

\section{PEMBAHASAN}

\section{Pengaruh Nilai Z-Score Terhadap Profitabilitas (ROA)}

Hasil penelitian menunjukkan bahwa nilai Z-Score berpengaruh terhadap profitabilitas. Hal ini ditunjukkan dengan nilai probabilitas sebesar 0,017 (Tabel 2). Nilai ZScore merupakan skor yang ditentukan dari hitungan standar kali nisbah-nisbah keuangan yang menunjukkan tingkat kemungkinan kebangkrutan perusahaan. Nisbah-nisbah yang digunakan meliputi Working Capital / Total Asset, Retained Earnings / Total Asset, Earnings Before Interest And Taxes / Total Asset, Market Capitalization / Book Value Of Debt dan Sales / Total Asset. Nilai Z-Score yang semakin tinggi, menunjukkan perusahaan akan semakin baik. Nisbah-nisbah yang digunakan 
dalam perhitungan Z-Score menunjukkan proporsi dana yang digunakan untuk pengembangan usaha terhadap aset, sehingga semakin besar proporsi dana akan semakin tinggi Z-Score yang senajutnya akan berdampak pada profitabilitas usaha.

\section{Pengaruh Struktur Modal (DER) Terhadap Profitabilitas (ROA)}

Pengaruh DER terhadap profitabilitas menunjukkan bahwa DER tidak berpengaruh terhadap profitabilitas (Tabel 2). Karakteristik struktur modal bank berbeda secara fundamental dengan perusahaan non keuangan. Sumber pendanaan Sebagaimana diketahui bahwa ada tiga sumber dana bagi bank, yaitu dana pihak pertama atau dari pemilik, dana dari pihak kedua, yaitu hutang dan dana pihak ketiga (DPK) atau Dana masyarakat. Dimana DPK merupakan sumber utama bagi bank untuk menyalurkan kredit. Sedangkan dana hutang dan modal sendiri (ekuitas) merupakan sumber dana yang relative kecil. DER merupakan rasio antara hutang dengan modal sendiri, sehingga untuk bank dimana sumber dana dari hutang kecil dan cenderung bukan merupakan sumber utama bank dalam menyalurkan kredit. Sehingga besar kecilnya DER cenderung tidak berpengaruh terhadap profitabilitas bank.

Temuan penelitian ini relevan dengan penelitian Fachrudin (2011), Wibowo dan Wartini (2012) dimana struktur modal tidak berpengaruh terhadap profitabilitas. Namun hasil penelitian ini tidak relevan dengan temuan penelitian Haryanto (2016), Bukit (2012), Agiomirgianakis dan Magoutas (2012), dan Wahyuni (2012), dimana struktur modal berpengaruh dengan arah positif terhadap profitabilitas.

\section{Pengaruh Size Terhadap Profitabilitas (ROA)}

Size menunjukkan besar kecilnya suatu perusahaan yang dapat diukur kekayaan yang dimiliki, yaitu asset. Hasil penelitian menunjukkan bahwa Size berpengaruh positif terhadap profitabilitas bank dengan arah positif. Artinya semakin besar asset suatu bank, maka bank tersebut akan cenderung mampu membulukan profitabilitas yang semakin tinggi. Aset bank dominan dibiayai dari DPK, dimana bank sebagai lembaga intermediasi maka DPK tersebut akan disalurkan kepada masyarakat dalam bentuk kredit. DPK bank-bank nasional menopang sekitar 80 persen dari sumber pembaiyaannya. Bank dengan DPK yang tinggi, maka asetnya akan cenderung besar sehingga bank tersebut akan memiliki potensi menyalurkan kredit yang semskin besar. Secara tradisonal pendapatan bank masih bersumber dari suku bunga kredit, sehingga dengan kredit yang semakin besar pendapatan bank akan semakin tinggi. Bank sebagai lembaga intermediasi akan mampu menyalurkan kredit dalam jumlah yang besar jika bank mampu menghimpun DPK yang besar.

Temuan penelitian ini relevan dengan temuan penelitian yang dilakukan Lin (2006), Rodoni (2002), Pangemanan dan Mawikere (2011) dimana perusahaan besar lebih menjanjikan kinerja yang baik. Hasil penelitian Sunarto dan Budi (2009) menunjukkan bahwa Size berpengaruh terhadap profitabilitas. Penelitian ini tidak mendukung temuan penelitian Indarti dan Extaliyus (2013) dimana Size tidak berpengaruh terhadap kinerja perusahaan, dimana kinerja perusahaan diukur dengan ROE.

\section{Pengaruh Risiko Kredit (NPL) Terhadap Profitabilitas (ROA)}

Kredit bermasalah atau NPL merupakan risiko yang harus dihadapi oleh bank sebagai lembaga intermediasi. Semakin tinggi NPL menunjukkan semakin tinggi risiko yang harus dihadapi oleh suatu bank. Hasil penelitian menemukan bahwa risiko kedit berpengaruh terhadap profitabilitas dengan arah negative. Artinya semakin tinggi risiko kredit yang ditunjukkan oleh NPL yang semakin tinggi maka profitabilitas bank akan semakin rendah.

Bank dengan NPL yang tinggi menunjukkan kredit macet bank tinggi. Bank dengan kredit macet yang tinggi menunjukkan bahwa banyak debitur yang mengalami masalah dalam membayar angsuran ke bank. Ketika angsuran dari debitur bermasalah, maka bank akan kesulitan menyalurkan kredit dari dana 
yang seharusnya diputar sehingga akan berpengaruh pada profitabilitas bank. Selain itu dengan NPL yang tinggi bank harus menyediakan dana yang lebih untuk mencover risiko kredit tersebut. Kondisi demikian tentunya akan mempengaruhi kemampuan bank dalam menyalurkan kredit. Hal ini menunjukkan apabila kredit bermasalah meningkat, maka risiko terjadinya penurunan profitabilitas semakin besar. Ketika profitabilitas bank menurun, akan berakibat pada kemampuan bank dalam melakukan ekspansi kredit berkurang.

Hasil penelitian ini mendukung temuan penelitian Haryanto (2016), Hutagalung dkk (2013), Eng (2013) dimana NPL berpengaruh terhadap ROA. Hasil temuan ini tidak mendukung temuan penelitian Negara dan Sujana (2014), Suhardi dan Altin (2013) dimana NPL tidak berpengaruh terhadap ROA.

\section{Pengaruh Permodalan (CAR) Terhadap Profitabilitas (ROA)}

Salah satu permasalahan yang sangat penting bagi industry perbankan nasional adalah permodalan bank atau CAR. Bank dituntut untuk dapat memenuhi kebutuhan CAR minimum sebesar 8 persen. Bahkan jika bank mampu bersaing secara global, maka dituntut memiliki CAR yang besar. CAR bagi bank berfungsi menampung risiko kerugian yang kemungkinan dihadapi oleh bank. Hasil penelitian menunjukkan bahwa CAR berpengaruh positif dan signifikan terhadap Profitabilitas.

Bank dengan CAR yang semakin tinggi, maka bank tersebut akan semakin baik kemampuannya untuk melakukan ekspansi usaha. Jika CAR tinggi maka bank tersebut akan mampu membiayai kegiatan operasional dan memberikan kontribusi yang cukup besar bagi profitabilitas. Sehingga bank dengan CAR yang tinggi, ketika bank harus mengalokasikan pembiayaan yang cukup besar untuk kreditnya akan mampu discover oleh modal, sehingga tidak menganggu likuiditas bank.

Temuan penelitian mendukung temuan penelitian yang dilakukan Sudiyatno dan Suroso (2010) CAR berpengaruh terhadap ROA. Namun tidak mendukung penelitian Hutagalung dkk (2013) Natalina dkk (2012), Sudiyatno dan Fatmawati (2013) dimana hasil penelitian menunjukkan CAR tidak berpengaruh terhadap ROA.

\section{SIMPULAN DAN SARAN}

Berdasarkan hasil analisis dan pembahasan dapat disimpulan bahwa nilai ZScore, Size, risiko kredit, dan permodalan bank (CAR) secara parsial berpengaruh terhadap profitabilitas. Nilai Z-Score, Size, dan permodalan bank (CAR) berpengaruh positif terhadap profitabilitas, sedangkan risiko kredit berpengaruh negative terhjadap profitabilitas. Variabel struktur modal (DER) tidak berpengaruh terhadap profitabilitas. Hal ini mengingat struktur modal bank atau lembaga keuangan berbeda dengan struktur modal perusahaan non keuangan. Dimana lembaga sumber dana bank dominan dari DPK, bukan dari hutang.

Penelitiaan ini terbatas dengan variable nilai Z-Score, Size, risiko kredit, dan permodalan bank (CAR) sebagai variable prediktor profitabilitas bank, dengan objek BUSN dan periode penelitian tahun 2013-2014. Untuk penelitian yang selanjutnya dapat dilakukan dengan objek lebih luas dan periode yang lebih panjang. Variabel untuk mengidentifikasi profitabilitas dapat ditambhkan dengan lain, seperti cost of capital (COC).

\section{DAFTAR PUSTAKA}

Adnan, Muhammad Akhyar., dan Kurniasih, Eha. 2000. Analisis Tingkat Kesehatan Perusahaan untuk Memprediksi Potensi Kebangkrutan dengan Pendekatan Altman (Kasus pada Sepuluh Perusahaan di Indonesia). Jurnal Akuntansi dan Auditing Indonesia. Vol. 4 (2).

Agiomirgianakis, M George dan Magoutas, I Anastasios. 2012. Determinants of profitability and the decision-making process of firms in the tourism sector: the case of Greece. Int. J. Decision Sciences, Risk and Management, Vol. 4. 
Ali, Mashud. 2004. Asset Liability Management : Menyiasati Risiko Pasar dan Risiko Operasional. Jakarta : PT. Gramedia

Ardrian, Andromeda dan Khoiruddin, Mohammad. 2014. Pengaruh Analicic Kebangkrutan Model Altman Terhar 9 Harga Saham Perusahaan Manufaktur. Management Analysis Journal. 3 (1).

Altman, E.I. 1968. Financial Ratios, Discriminant Analysis and the Prediction of Corporate Bankcuptcy. Journal of Finance 23.

Astohar. 2009. Analisis Faktor yang Mempengaruhi Profitabilitas Perbankan Di Indonesia (Studi Pada Bank Domestik, Bank Campuran dan Bank Asing). (Tesis). Universitas Diponegoro Semarang.

Bourke, P. 1989. Concentration and Other Determinants of Bank Profitability in Europe, North America and Australia. Journal of Banking and Finance. Vol. 13 (1).

Brigham, Eugene F \& Erhardt, Michael C. 2005. Financial Management : Theory and Pratice. Eleventh Edition. Thomson Corporation, South Western

Bukit, Br. Rina. 2012. Pengaruh Struktur Modal Terhadap Nilai Perusahaan Melalui Profitabilitas: Analisis Data Panel Perusahaan Manufaktur Di Bursa Efek Indonesia. Jurnal Keuangan dan Bisnis Vol. 4 (3).

Eng, Sau Tan. 2013. Pengaruh NIM, BOPO, LDR, NPL dan CAR Terhadap ROA Bank Internasional dan Bank Nasional Go Public Periode 2007-2011. Jurnal Dinamika Manajemen (JDM).Vol. 1 (3).

Fachrudin, Khaira Amalia. 2011. Analisis Pengaruh Struktur Modal, Size dan Agency Cost Terhadap Kinerja Perusahaan. Jurnal Akuntansi dan Keuangan. Vol 13 (1)

Fitrianto, Hendra dan Mawardi, Wisnu. 2006. Analisis Pengaruh Kualitas Aset,Likuiditas, Rentabilitas, dan Efisiensi Terhadap Rasio Kecukupan Modal Perbankan yang Terdaftar di Bursa
Efek Jakarta. Jurnal StudiManajemen \&Organisasi.

Gelos, G.R. 2006. Banking Spreads in Latin America. IMF Working Paper 06/44. International Monetary Fund.

Gitman, Lawrence J. 2009. Principles of Managerial Finance. Twelfth Edition. The Addison Wesley Publishing.

Hapsari, Evanny Indri. 2012. Kekauatan Rasio Keuangan Dalam Memprediksi Kondisi Financial Distress Perusahaan Manufaktur di BEI. Jurnal Dinamika Manajemen. Vol. 3 (2).

Haryanto, Sugeng. 2016. Profitability Identification of National Banking Through Credit, Capital Structure, Efficiency and Risk Level. Jurnal Dinamika Manajemen. Vol. 7 (1)

--------. 2015. Determinan Capital Buffer: Kajian Empirik Industri Perbankan nasional. Jurnal Ekonomi Modernisasi. Vol. 11 (2). -2014. Identifikasi Ekspektasi Investor Melalui Kebijakan Struktur Modal, Profitabilitas, Size dan GCPI. Jurnal Dinamika Manajemen. Vol. 5 (2)

Hutagalung, Novelina Esther. Djumahir dan Ratnawati, Kusuma. 2013. Analisa Rasio Keuangan terhadap Kinerja Bank Umum di Indonesia. Jurnal Aplikasi Manajemen. Vol. 11 (1).

Husnan, Suad dan Enny Pudjiastuti. 2004. Dasar-dasar Manajemen Keuangan (Edisi ke-6) Yogyakarta: UPP STIM YKPN.

Indarti, MG. Kentris dan Extaliyus, Lusi. 2013. Pengaruh Corporate Governance Perception Index (CGPI), Struktur Kepemilikan dan Size Terhadapp Kinerja Keuangan. Jurnal Bisnis dan Ekonomi (JBE). Vol. 20 (2)

Karina dan Khafid, Muhammad. 2015. Determinan Profitabilitas Pada Perushaan Properti Dan Real Estate Go Publik Di Indonesia. Jurnal Dinamika Akuntansi. Vol. 7 (1).

Kristantri, Rr. Tisyri Manuella dan Ni Ketut Rasmini. 2012. Analisis Faktor-Faktor yang Mempengaruhi Profitabilitas 
Dengan Pertumbuhan Laba Sebagai Variabel Moderasi. Jurnal Akuntansi dan Keuangan. Vol. 1 (2).

Limpaphayom, Piman, dan Siraphat Polwitoon. 2004. Bank Relationship and Firm Performance: Evidence from Thailand before The Asian Financial Crisis. Journal of Bussiness Finance and Accounting.

Lin, K. L. 2006. Study on Related Party Transaction with Mainland China in Taiwan Enterprises. Unpublished Dissertation. China: Departemen Manajemen, Universitas Guo Li Cheng Gong

Mabruroh. 2004. Manfaat Pengarug Rasio Keuangan Dalam Analisis Keuangan Perbankan. Benefit. Vol. 8 (1).

Merkusiwati, Ni Ketut Lely Aryani. 2007. Evaluasi Pengaruh Camel Terhadap Kinerja Perusahaan. Buletin Studi Ekonomi. Vol. 12 (1).

Moh'd, M. A., Perry, L. G., \& Rimbey, J. N. 1998. The impact of ownership structure on corporation debt policy: A time-series cross-sectional analysis. The Financial Review. 3.

Molyneux, P. \& Thornton, J. 1992. Determinan of European Bank Profitability: A Note. Journal of Banking and Finance. Vol. 16 (6).

Natalina, Ary. Pratiwi, Widi dan Nariya, Andi. 2012. Analisis Capital Adequacy Ratio (CAR) dan Aktiva Tetap Terhadap Modal (ATTM) terhadap Profitabilitas Pada PT Bank Permata, Tbk. UG Jurnal Vol. 6 (12)

Negara, I Putu Agus Atmaja dan Sujana, I Ketut, 2014. Pengaruh Capital Adequacy Ratio, Penyakuran Kredit dan Non Performing Loan Pada Profitabilitas. EJurnal Akuntansi Universitas Udayana. Vol. 9 (2).

Nugraha, Arif Adhi. 2013. Analisis Pengaruh Struktur Modal Terhadap Kinerja Perusahaan Yang Tergabung Dalam Indeks Kompas 100. Management Analysis Journal (MAJ). Vol. 2 (1)

Pangemanan, S \& Mawikere, L. 2011. Pengaruh Size dan Pertumbuhan Perusahaan
Terhadap Earning Per Share Pada Industri Tekstil Di Bursa Efek Indonesia. Jurnal Riset Akuntansi dan Auditing Goodwill. Vol. 2 (1).

Platt dan Platt. 2006. Understanding Differences

Between Financial Distress and

Bankruptcy. Review of Applied Economies. Vol. 2 (2).

Priantana, Riha Dedi dan Zulfia. 2011. Pengaruh Rasio Kecukupan Modal, NonPerforming Loan, dan Tingkat Likuiditas terhadap Profitabilitas Perbankan yang Terdaftar di Bursa Efek Indonesia. Jurnal Akuntansi dan Keuangan. Vol. 1 (1).

Prihadi, Toto. 2008. Deteksi Cepat Kondisi Keuangan: Tujuh Analisis Rasio Keuangan. Pengembangan Eksekutif. Jakarta

Sari, Yulimel. 2013. Pengaruh Profitabilitas, Kecukupan Modal dan Likuiditas Terhadap Harga Saham (Perusahaan Perbankan yang Terdaftar di BEI). Jurnal Akuntansi. Vol. 1(1).

Saunders, Antony, Garnett M. Millon. 2008. Financial Institutions Management: A Risk Management Approach. Sixth Edition. Mc Graw-Hill International Edition, New York.

Siringoringo, Renniwaty. 2012. Karakteristik Dan Fungsi Intermediasi Perbankan Di Indonesia. Buletin Ekonomi Moneter dan Perbankan. Juli 2012.

Sofyan, S. 2013. Keputusan Go Public dan Hubungannya dengan Bank-Bank Swasta di Indonesia. Jurnal Media Riset \& Manajemen. Vol. 3 (1).

Subandi dan Ghozali, Imam. 2013. Determinan Efisiensi Dan Dampaknya Terhadap Kinerja Profitabilitas Industri Perbankan Di Indonesia. Jurnal Keuangan dan Perbankan. Vol.17 (1).

Sudiyatno, Bambang dan Suroso, Jati. 2010. Analisis Pengaruh Dana Pihak Ketiga, BOPO, CAR dan LDR Terhadap Kinerja Keuangan Pada Sektor Perbankan Yang Go Public Di Bursa Efek Indonesia (BEI) Periode 2005-2008. Dinamika Keuangan dan Perbankan, Vol. 2 (2). 
Sudiyatno, Bambang dan Fatmawati, Asih. 2013. Pengaruh Risiko Kredit dan Efisiensi Operasional Terhadap Kineria Bank (Studi Empirik Pada Bank 11 Terdaftar di Bursa Efek Indonesia). Jurnal Organisasi dan Manajemen, Volume 9 (1).

Suhardi dan Altin, Darus. 2013. Analisis Kinerja Keuangan Bank BPR Konvensional di Inondeia Periode 20092012. Pekbis Jurnal. Vol. 5 (2).

Sujoko dan Ugi. Soebiantoro. 2007. Pengaruh Struktur Kepemilikan Saham, Leverage Faktor Intern dan Faktor Ekstern terhadap Nilai Perusahaan. Jurnal Manajemen dan Kewirausahaan. Vol. 9 (1).

Sunarto dan Budi, Agus Prasetyo. 2009. Pengaruh Leverage, Ukuran dan Pertumbuhan Perusahaan Terhadap Profitabilitas. Jurnal TEMA Vol. 6 (1)

Suteja, Jaja dan Ginting, Gerinata. 2014. Determinan Profitabilitas Bank: Suatu Studi pada Bank yang Terdaftar di BEI. Jurnal Trikonomika. Vol. 13(1).

Suyono, Agus. 2005. Analisis Rasio-Rasio Bank yang Berpengaruh terhadap Return on Asset (ROA). (Tesis). Semarang: Universitas Diponegoro.

Wahyuni, Sri. 2012. Efek struktur Modal Terhadap Profitabilitas Pada Perusahaan Manufaktur Yang Terdaftar Di Bursa Efek Indonesia. Management Analysis Journal (MAJ). Vol. 1 (2).

Wibowo, Agus dan Wartini, Sri. 2012. Efisiensi Modal kerja, Likuiditas dan leverage terhadap Profitabilitas Pada Perusahaan Manufaktur di BEI. Jurnal Dinamika Manajemen (JDM) Vol. 3 (1) 